\title{
A QUESTÃO DO ESTADO E OS PRISMAS DA PEDAGOGIA HISTÓRICO-CRÍTICA NA TRANSIÇÃO DO CAPITALISMO PARA O SOCIALISMO/COMUNISMO.
}

\author{
LA CUESTIÓN DEL ESTADO Y LOS PRISMAS DE LA PEDAGOGÍA HISTÓRICA \\ CRÍTICA EN LA TRANSICIÓN DEL CAPITALISMO AL SOCIALISMO/COMUNISMO.
}

\begin{abstract}
THE QUESTION OF THE STATE AND THE PRISMS OF CRITICAL HISTORICAL PEDAGOGY IN THE TRANSITION FROM CAPITALISM TO SOCIALISM/COMMUNISM.
\end{abstract}

DOI: https://doi.org/10.9771/gmed.v13i3.44984

Danielle do Nascimento Rezer ${ }^{1}$

Walson Lopes ${ }^{2}$

\begin{abstract}
Resumo: Neste artigo, buscamos debater como os teóricos Karl Marx, Nicos Poulantzas e Antonio Gramsci nos oferecem subsídios para problematizar o Estado na sociedade capitalista e o caminho de sua superação, pela via socialista, no processo de formação da sociabilidade comunista. Sem embargo, nos amparamos nos aportes da Pedagogia Histórico-Crítica que no campo da educação, com seus referenciais didático-pedagógicos, muito contribui para esse processo de mediação de suplantação da sociedade produtora de mercadorias, para uma sociedade em que o ser humano possa emancipar-se, ultrapassando as iniquidades e a reificação tão características da forma social capitalista.
\end{abstract}

Palavras-chave: Estado capitalista; Pedagogia Histórico-Crítica; Transição do capitalismo para o socialismo/comunismo; Luta de classes.

Resumen: En este artículo, buscamos discutir cómo los teóricos Karl Marx, Nicos Poulantzas y Antonio Gramsci nos ofrecen subsidios para problematizar el Estado en la sociedad capitalista y el camino para su superación, por la vía socialista, en el proceso de formación de la sociabilidad comunista. Sin embargo, contamos con los aportes de la Pedagogía Histórica Crítica que, en el campo de la educación, con sus referencias didáctico-pedagógicas, contribuye mucho a este proceso de mediación de la suplantación de la sociedad productora de mercancías, hacia una sociedad en la que el ser humano pueda emanciparse, superando las desigualdades y la cosificación tan características de la forma social capitalista.

Palabras clave: Estado capitalista; Pedagogía histórica crítica; Transición del capitalismo al socialismo/comunismo; Lucha de clases

Abstract: In this article, we seek to discuss how the theorists Karl Marx, Nicos Poulantzas and Antonio Gramsci offer us subsidies to problematize the State in capitalist society and the path to its overcoming, through socialism, in the process of formation of communist sociability. However, we rely on the contributions of Critical Historical Pedagogy that, in the field of education, with its didactic and pedagogical references, contributes a lot to this mediation process of supplanting the commodity-producing society, towards a society in which human beings can emancipate themselves, overcoming the inequities and the reification so characteristic of the capitalist social form.

Keywords: Capitalist state; Critical historical pedagogy; Transition from capitalism to socialism/communism. 


\section{O Estado em Marx, Poulantzas e Gramsci}

Mais que urgente e atual, vemos ser imperioso discutir as determinações estruturais e superestruturais de nossa sociedade. Entendemos que sob a ótica da compreensão do Estado podemos repensar novas abordagens no enfrentamento das desigualdades, que se apresentam em diversos contextos e padrões. Na contemporaneidade, enfrentamos desafios de grande monta associados a uma crise geral e mundial que, conforme Foster, Holleman e Clark (2019), são fomentadas pela lógica de alienação em diversas áreas do processo produtivo, e se estende à alienação do metabolismo social e da natureza. Pelo enfoque da totalidade dos movimentos, engodos e artimanhas alienantes e autoritárias do capitalismo e suas formas, é que devemos pensar o estado de coisas que se dissemina em variados domínios da sociedade, dinamizando a crise orgânica do capital.

Ou seja, é fundamental compreendermos as reais possibilidades de resistência no campo da transformação qualitativa, baseada em estratégias críticas que se sustentem numa luta contra esse sistema sociometabólico. Neste sentido, considerando tais questões, buscamos neste artigo fundamentar a partir de Marx, Poulantzas e Gramsci, o conceito de Estado e seu papel na luta de classes. Retemos, como aspecto fundamental entre os autores, a necessária tomada de consciência crítica das classes subalternas sobre sua condição e concretas potencialidades de uma práxis transformadora do status quo. Para tal intento, nos calçamos na concepção pedagógica "savianiana" histórico-crítica, na perspectiva de uma educação não tecnicista, mas sim de uma formação integral ou omnilateral, cuja prática norteadora é exceder o senso comum hegemônico e as desigualdades socioeconômicas capitalistas.

Desse modo, iniciamos nossa discussão pelos conceitos de Estado em Marx, Poulantzas e Gramsci. Começando por Karl Marx, não nos parece arbitrário afirmar que o pensamento marxiano está centrado na análise da organização, funcionamento e fundamentalmente nas contradições do sistema capitalista. Mais do que isso, em seus escritos percebemos a preocupação precípua em nos apresentar instrumentos teóricometodológicos que apontem para a supressão do capitalismo, rumo à construção de novas relações sociais sob as quais a primazia do capital seja suplantada pela centralidade do trabalho ontogenérico. Mas como viabilizar essa nova sociedade? Como construir esse novo homem? Quais mecanismos devem ser utilizados?

Partindo dos pressupostos de que "Os homens fazem sua própria história, mas não a fazem como querem; não a fazem sob circunstâncias de sua escolha e sim sob aquelas com que se defrontam diretamente, legadas e transmitidas pelo passado" (MARX, 1974, p. 335); e também que "Até hoje a história de todas as sociedades que existiram até nossos dias tem sido a história das lutas de classes" (MARX e ENGELS, 1960, p. 24), o precursor do materialismo histórico afirmará que numa sociedade dividida em classes sociais, como a capitalista, caberá ao proletariado a tarefa, em confronto com a burguesia, detentora dos meios de produção, de destruir o Estado que se estrutura como um aparelho político de classe de legitimação e reprodução das relações capitalistas de produção. Nesse sentido, as seguintes passagens seminais do Manifesto do Partido Comunista são esclarecedoras: "O governo moderno não é senão um comitê para gerir os negócios comuns de toda a classe burguesa" (ibid., p. 26), e 
O proletariado utilizará sua supremacia política para arrancar pouco a pouco todo capital à burguesia, para centralizar todos os instrumentos de produção nas mãos do Estado, isto é, do proletariado organizado em classe dominante, e para aumentar, o mais rapidamente possível, o total das forças produtivas (ibid., p. 48)

Para Marx, em síntese, considerando o socio-metabolismo do modo de produção do capital, a classe trabalhadora viverá sempre sob a lógica do "vampiro": daí a perspectiva de transcender "do reino das necessidades, para o reino da liberdade".

Os parágrafos anteriores ressaltam a importância e a preocupação com o aparelho de Estado nas análises de Marx, não só na dinâmica socio-metabólica do capitalismo, mas igualmente no processo de luta "para além do capital". Entretanto, não se pode aferir que há nos escritos marxianos uma defesa dele ad eternun. É evidente que o Estado proletário cumprirá uma função muito relevante na construção do comunismo, mas apenas em caráter instrumental. Ou seja, o Estado socialista é um meio e não um fim: desempenhará um significativo papel de transição do capitalismo para o comunismo. Podemos dizer que Marx ao mesmo tempo em que o afirma, nega-o. Se, de um lado, na Crítica ao Programa de Ghota, ele escreve:

Entre a sociedade capitalista e a sociedade comunista medeia o período da transformação revolucionária da primeira na segunda. A este período corresponde também um período político de transição, cujo Estado não pode ser outro senão a ditadura revolucionária do proletariado (MARX, 1975, p. 239, grifos nossos).

Portanto, defendendo a existência de um Estado proletário transitório; de outro lado, no livro A Guerra Civil na França, em que analisa a insurreição operária e popular de 1871, argumenta:

[...] No breve esboço de organização nacional que a comuna não teve tempo de desenvolver, diz-se claramente que a Comuna devia ser a forma política inclusive das menores aldeias do país e que nos distritos rurais o exército permanente devia ser substituído por uma milícia popular, com um tempo de serviço extraordinariamente curto. As comunas rurais de cada distrito administrariam seus assuntos coletivos por meio de uma assembleia de delegados na capital do distrito correspondente e essas assembleias, por sua vez, enviariam deputados à delegação nacional em Paris, entendendo-se que todos os delegados seriam substituídos a qualquer momento e comprometidos com um mandato imperativo de seus eleitores [...] Não se tratava de destruir a unidade da nação, mas, ao contrário de organizá-la mediante um regime comunal, convertendo-a numa realidade ao destruir o poder estatal (MARX, 1975, p. 197-198, grifos nossos).

Eis aí a negação do Estado no pensamento marxiano. Se equivocam aqueles que defendem, proclamando uma pretensa fundamentação em Marx, que o Estado restrito deve concentrar, por um certo período de tempo, apenas em seu aparato burocrático toda e qualquer decisão política no processo revolucionário de construção do socialismo. Como escreveu Engels, no ano de 1891, em comemoração ao vigésimo aniversário da Comuna de Paris: “olhai para a Comuna de Paris: eis aí a ditadura do proletariado!".

Não cabe neste trabalho discutir a complexidade teórica e as polêmicas que envolvem a concepção de ditadura do proletariado no campo marxista ${ }^{3}$. No entanto, antes de tecermos alguns comentários sobre os pensamentos de Nicos Poulantzas e Antonio Gramsci, é necessário trazer à lume como se apresenta no ideário marxiano a conquista do poder político pelo proletariado: condição sine qua non para sobrepujar a dominação de classe burguesa. 
Ora, se na sociedade capitalista, segundo Marx (1958), existem duas classes sociais fundamentais Burguesia e Proletariado - antagônicas, que a primeira objetiva edificar um "mundo social à sua imagem e semelhança"; e que o Estado, de acordo com o Marx do Manifesto, é uma expressão política dos interesses exclusivos de classe da burguesia, não resta outra alternativa à classe produtora para emancipar-se senão a sua organização em "classe para si”. Ou seja, uma classe que se reconheça portadora de novos e imprescindíveis valores socioeconômico-políticos igualitários; e pugna para concretizá-los estabelecendo novas relações sociais de produção. Por consequência, os trabalhadores não podem se furtar dessa luta de classes e da revolução como preceitos basilares para atingir essa nova sociedade: sem classes e, o que seria um truísmo para Marx, sem Estado.

Mas como devem se organizar precisamente os trabalhadores no enfrentamento ao poder burguês? “O primeiro grande passo a ser dado em todos os países que tenham recentemente entrado em movimento [de massas] é a constituição dos operários em partido político independente, não importando como, mas bastando somente que ele seja um partido operário distinto" (ENGELS, 1978, p. 26), elucida Engels numa carta escrita a seu amigo Sorge, em 1886. Marx também chamou a atenção para o caráter independente do partido proletário no transcorrer da luta de classes:

Mas eles [os operários] devem, por si mesmos, fazer o máximo possível por sua vitória, esclarecendo-se sobre seus interesses de classe, adotando o mais cedo possível uma posição de partido independente e recusando-se a ser dissuadidos, pelas belas e hipócritas palavras da pequena-burguesia democrática, da organização independente do partido do proletariado. É necessário que seu grito de guerra seja: A Revolução Permanente (MARX, 1978, p. 23)

Destarte, é facilmente identificável no pensamento de Karl Marx a apologia da organização da classe operária em partido político autônomo das frações burguesas. Não obstante, isso não quer dizer que em determinadas questões um partido proletário não possa atuar conjuntamente com alguma ou algumas dessas frações para evitar ou derrotar regimes fascistas, por exemplo. O que não deve acontecer jamais é rebaixar suas perspectivas históricas: a libertação do trabalho sob domínio do capital.

Não é possível neste texto, pois fugiria da proposta inicial, analisar as diferentes concepções de partido político existentes nas diversas correntes marxistas. Leninistas e Luxemburguistas que o digam: partido de quadros ou de massas? Mas quem disse que os dois são excludentes? Essas questões são importantes para o movimento operário nacional e internacional; mas como já foi sublinhado, não é o eixo deste trabalho estudar essas variações marxistas.

Contudo, uma coisa é certa: o proletariado deve se organizar em partido político. Tal assertiva foi lançada categoricamente por Marx e Engels no histórico Manifesto do Partido Comunista de 1848. Este partido não seria simplesmente para o proletariado, mas sim dirigido pelo proletariado. Essa ressalva é importante para esclarecer que o partido político concebido pelo revolucionário alemão não faria a revolução para os trabalhadores, isolando as massas da direção do processo revolucionário e da condução da transição do capitalismo para o comunismo, faria para e com as massas em movimento. 
Portanto, podemos sugerir que a concepção política em Marx está dimensionada no âmbito da luta de classes. Nesse sentido, fazer política numa dimensão marxista é lutar contra a exploração do capital e pela destruição do poder político da burguesia objetivado no Estado. Ou seja, é lutar pela construção de novas relações sociais de produção onde não haja poder político (Estado) e muito menos relações humanas reificadas. Segundo os fundadores do socialismo científico:

O poder político é o poder organizado de uma classe para a opressão de outra. Se o proletariado, em sua luta contra a burguesia, se constitui forçosamente em classe, se se converte por uma revolução em classe dominante e, como classe dominante, destrói justamente com essas relações de produção, as condições dos antagonismos entre as classes, destrói as classes em geral e, com isso, sua própria dominação como classe (MARX e ENGELS, 1958, p. 49).

Desta breve incursão no pensamento de Marx, devemos reter substancialmente que, em sua análise sobre a sociedade burguesa em meados do século XIX, o Estado não é um aparelho neutro ou que está acima dos conflitos de classe, ele expressa sempre o poder político da classe capitalista. Todavia, essa concepção de Estado do filósofo alemão, apesar de ter captado o busílis do problema, que o Estado é a expressão do poder político de uma classe sobre outra(s) numa determinada sociedade, como igualmente interpreta Lenin: "Para Marx, o Estado é um órgão de dominação de classe, um órgão de submissão de uma classe por outra; é a criação de uma 'ordem' que legalize e consolide essa submissão, amortecendo a colisão das classes" (LENIN, 2007, p. 26, grifos originais); é possível sustentar que essa compreensão restrita de Estado foi saturada por novas determinações que contribuíram para avançar, no século XX, não só na apreensão da realidade concreta da sociedade produtora de mercadorias que se complexificava, mas inclusive na formulação de aportes teórico-metodológicos delineando renovadas possibilidades de abolição dessas relações capitalistas de produção.

O cientista político grego, naturalizado francês, Nicos Poulantzas foi um desses pensadores no campo marxista que adensaram concretude à categoria Estado; mais precisamente ao Estado capitalista. Segundo esse teórico, em Marx (e do mesmo modo em Engels) se encontram apenas indícios ou "princípios gerais de uma teoria de Estado", isto é, não se constata "verdadeiramente uma teoria do Estado" no arcabouço teórico de Marx, muito menos do Estado capitalista. Além disso, o referido pensador manifesta contrariedade à leitura reducionista de Estado em Lenin que "parece evidente que nos [seus] textos exista uma concepção instrumentalista do Estado", pressupondo uma percepção de "Estado enquanto bloco monolítico, sem fissuras"”.

Para Poulantzas, reduzir a materialidade do Estado à "ferramenta ou instrumento não tem pertinência política", não capta substancialmente que as contradições de classe não apenas engendram o Estado, mas que essas mesmas contradições estão arraigadas no próprio seio de sua ossatura institucional. Portanto,

divisões de classe, não é, não pode ser jamais, como nas concepções do Estado-Coisa ou Sujeito, um bloco monolítico sem fissuras, cuja política se instaura de qualquer maneira a despeito de suas contradições, mas é ele mesmo dividido [...] As contradições de classe 
constituem o Estado, presentes na sua ossatura material, e armam assim sua organização: a política do Estado é o efeito de seu funcionamento no seio do Estado (POULANTZAS, 1979, p. 152)

Dessa definição poulantziana, em resumo, devemos assimilar o Estado como uma relação social, "mais exatamente como a condensação material de uma relação de forças entre classes e fraçōes de classe" (ibid., p. 147, grifos originais) que empreendem disputas pela hegemonia política no bloco de poder ${ }^{5}$. Desse modo, as políticas estatais devem ser consideradas como resultantes dessas "contradições de classe inseridas na própria estrutura do Estado" (ibid., p. 152).

O Estado na sociedade capitalista, abordagem cêntrica na produção epistêmica de Nicos Poulantzas, desempenha a incumbência principal de organizar e unificar as classes dominantes em sua estrutura material. Porém, o "Estado detém sempre uma autonomia relativa em relação a essa ou aquela fração do bloco no poder [...] a fim de assegurar a organização do interesse geral da burguesia sob a hegemonia de uma de suas frações" (ibid., p. 147, grifos nossos).

Se de um lado, o Estado congrega, fomenta a organicidade e a legitimidade dos interesses das classes dominantes, por outro, dialeticamente, esse mesmo Estado atua para desestruturar seus "inimigos de classe", como adverte o pesquisador greco-francês, ressaltando que "Os aparelhos de Estado organizam-unificam o bloco no poder ao desorganizar-dividir continuamente as classes dominadas, polarizando-as para o bloco no poder e ao curto-circuitar suas organizações políticas específicas" (ibid., p. 161). Nesse sentido, o Estado concentra em sua ossatura não somente "a relação de forças entre frações do bloco no poder, mas também a relação de forças entre estas e as classes dominadas" (ibid., p. 162, grifos originais). Por isso, o autor de O Estado, o poder, o socialismo reforça sua tese de que

O Estado não é nem o depositário instrumental (objeto) de um poder-essência que a classe dominante deteria, nem um sujeito que possua tanta quantidade de poder que, num confronto face a face, o tomaria das classes: o Estado é o lugar de organização estratégica da classe dominante em sua relação com as classes dominadas. É um lugar e um centro de exercício do poder, mas que não possui poder próprio (ibid., p. 169, grifos originais).

"Se as lutas de classe simultaneamente atravessam e constituem o Estado", como enfatiza Poulantzas, essa intelecção denota que as "classes populares" e suas lutas estão incrustadas no aparelho estatal como amálgama desse processo de enfrentamentos de classes e frações de classe. Ainda assim, ele admoesta que "As classes populares sempre estiveram presentes no Estado, sem que isso tenha modificado jamais alguma coisa no núcleo essencial desse Estado" (ibid., p. 165) capitalista. Outrossim, observa assertivamente que as ações dessas classes no interior do Estado são importantes, mas insuficientes para provocar profundas transformações do mesmo, que reproduz cotidianamente a ideologia dominante.

[...] do Estado neutro, representante da vontade e do interesse gerais, árbitro entre as classes em luta: a administração ou a justiça acima das classes, o exército pilar da nação, a polícia garantia da ordem republicana e das liberdades dos cidadãos, a administração motor da eficiência e do bem-estar geral (ibid., p. 179).

À vista disso, considerando que "Outubro de 1917" sob nenhuma forma poderia se repetir na Europa, conclui que só articulando, numa longa duração de tempo, as lutas interna e externa da ossatura 
institucional do Estado, as classes populares serão capazes de romper com a dominação do Estado capitalista (WEBER; POULANTZAS, 2019).

Nicos Poulantzas assinala que em sua teoria há “certos elementos” que "existem em Marx e Engels, Lenin e, sobretudo, Gramsci” (ibid., p. 192). Sem dúvida, o pensador italiano é um grande expoente da teorização do Estado na perspectiva marxista que lançou importantes subsídios para a sua problematização nas sociedades capitalistas contemporâneas avançadas. Como este artigo não tem o intuito primário de analisar as aproximações e distanciamentos teórico-metodológicos entre Poulantzas e Gramsci, o que não significa que não serão interpelados alguns tópicos dissonantes, vejamos o entendimento de Estado na literatura gramsciana.

O filósofo sardo, estando atento às variações socioeconômico-políticas e culturais dos países capitalistas ocidentais entre o final do século XIX e as primeiras décadas do século XX, depreendeu que as sociedades civis burguesas modernas estavam constituídas por aparelhos ou instituições complexas que formavam um "conjunto de organismos designados vulgarmente como 'privados"' (GRAMSCI, 2001, p. 20), que despendiam impulsos para contrarrestar ou legitimar e assegurar a reprodução do domínio das classes dirigentes. Por esse prisma, Antonio Gramsci amplia o conceito de Estado, na expressão de BuciGlucksmann (1980), incorporando ao seu delineamento teórico esses “aparelhos privados” (igrejas, escolas, partidos, sindicatos, jornais, revistas, empresas, associações etc.) que compõem a sociedade civil ${ }^{6}$, uma dimensão societária crivada de contradições perpassando as relações de produção e as disputas políticoideológicas, numa unidade-distinção, ao chamado Estado-restrito ou sociedade política (governo, tribunais, instituições legislativas, forças armadas etc.). Dessa forma, em suma, no pensamento gramsciano o Estado é a unidade-distinção entre sociedade política + sociedade civil ("hegemonia couraçada de coerção"), conformando um Estado orgânico ou integral ${ }^{7}$. Enquanto na sociedade política predomina o uso da coerção no exercício da dominação-direção, na sociedade civil são mobilizados dispositivos cuja função primordial é a construção do consenso. Isso não significa, como sublinham Bianchi (2008) e Jacomini (2020), que em ambas as esferas do Estado Integral não possam coexistir essas duas vertentes simultaneamente. Mas como enfatizou o autor marxista da Sardenha:

\section{O exercício 'normal' da hegemonia, no terreno tornado clássico do regime parlamentar, caracteriza-se pela combinação da força e do consenso, que se equilibram de modo variado, sem que a força suplante em muito o consenso, mas, ao contrário, tentando fazer com que a força pareça apoiada no consenso da maioria [...] (GRAMSCI, 2002, p. 95, grifos nossos).}

É oportuno deslindar e realçar que nessa ampliação conceitual de Estado, a sociedade civil é o locus privilegiado em que ocorrem embates de classes e frações de classe disputando projetos políticosocietais ${ }^{8}$ muitas vezes distintos ou até mesmo antagônicos. Por isso, a sociedade civil "nada tem de 'idílica' [...] é a arena da luta de classes" (MENDONÇA, 2014, p. 32, grifos originais) pelo domínio da "função hegemônica", isto é, de engendrar e dirigir um programa socioeconômico hegemônico equilibrando os "interesses diversos" da sociedade civil, indo além do "estreito interesse econômico-corporativo", logo, 
fazendo alguns "sacrifícios econômicos", conquistando os consensos "espontâneo" e "passivo" da maioria, constituindo uma "vontade coletiva", sem abandonar o uso da força sobre os grupos recalcitrantes para não comprometer os interesses fundamentais da classe que se faz hegemônica, como chama a atenção o autor dos Cadernos do cárcere:

[...] O fato da hegemonia pressupõe indubitavelmente que sejam levados em conta os interesses e as tendências dos grupos sobre os quais a hegemonia será exercida, que se forme um certo equilíbrio de compromisso, isto é, que o grupo dirigente faça sacrifícios de ordem econômico-corporativa; mas também é indubitável que tais sacrifícios e tal compromisso não podem envolver o essencial, dado que, se a hegemonia é ético-política, não pode deixar de ser também econômica, não pode deixar de ter seu fundamento na função decisiva que o grupo dirigente exerce no núcleo decisivo da atividade econômica (GRAMSCI, 2002, p. 48).

Nesse processo em que se confrontam grupos político-ideológicos que constituem e atravessam a sociedade civil e a sociedade política, Gramsci desvela que os intelectuais orgânicos ${ }^{9}$, atuando principalmente nos "aparelhos privados de hegemonia", cumprem uma tarefa imprescindível de divulgação, organização e direção desses projetos societais conflitantes na perspectiva de conformar uma ideologia hegemônica ${ }^{10}$ correspondente a um determinado tipo de modo de produção. No caso dos intelectuais orgânicos à burguesia, o modo de produção capitalista. Entrementes, é preciso estar atento ao que escreveu Bianchi:

A relação entre [os] intelectuais e o mundo da produção é mediada pelo conjunto das superestruturas das quais os intelectuais são funcionários. O grau de organicidade dos intelectuais pode ser medido através de uma gradação das superestruturas às quais estão vinculados (BIANCHI, 2008, p. 77).

Por conseguinte, se "O modo de ser do novo intelectual não pode mais consistir na eloquência, motor exterior e momentâneo dos afetos e das paixões, mas numa inserção ativa na vida prática, como construtor, organizador [e] 'persuasor permanente"' (GRAMSCI, 2001, p. 53), ou seja, indo muito além de compreender o intelectual como um erudito, escritor ou aquele que exerce uma atividade acadêmica, o intelectual orgânico gramsciano desempenha o ofício de persuadir, coligir e educar (não necessariamente nesta ordem) as massas seja para um "conformismo social" de reprodução do sistema econômico vigente ou na contingência de impulsionar uma reforma intelectual e moral propugnando uma nova hegemonia.

[...] numa determinada sociedade, ninguém é desorganizado e sem partido, desde que se entendam organização e partido num sentido amplo, e não formal. Nesta multiplicidade de sociedades particulares, de caráter duplo - natural e contratual ou voluntário -, uma ou mais prevalecem relativamente ou absolutamente, constituindo o aparelho hegemônico de um grupo social sobre o resto da população (ou sociedade civil), base do Estado compreendido estritamente como aparelho governamental-coercitivo (GRAMSCI, 2002, p. 253).

O que podemos constatar nessas formulações teóricas de Estado Integral, é que "O conceito de Estado no pensamento gramsciano está mais diretamente vinculado aos conceitos de hegemonia e de intelectual" (JACOMINI, 2020, p. 05), como tentamos exprimir neste trabalho. Além do mais, em sua concepção de Estado Ampliado, como síntese de uma correlação de forças, não há margem para dúvida quanto à negação de uma compreensão de Estado como reles instrumento da classe dominante-dirigente. Não se encontra em seus fundamentos teóricos uma "relação mecanicista entre Estado/classe" (BUCI- 
GLUCKSMANN, 1980, p. 29), aproximando Poulantzas de Antonio Gramsci. Apesar disso, distanciam-se a) à medida em que Nicos Poulantzas permanece com uma apreensão de Estado circunscrito à sociedade política; b) faz uma leitura enviesada do Estado e da Revolução na percepção do marxista sardo. Sobre as elaborações deste objetivando a transição do capitalismo ao socialismo nas "democracias modernas", expressou Poulantzas numa entrevista:

[...] Penso que, atualmente [1977], não se pode repetir Outubro [de] 17 sob nenhuma forma. A questão de fundo da revolução de Outubro não é apenas a oposição entre guerra de movimento e guerra de posição como Gramsci o definiu. Penso que Gramsci também permanece no esquema e no modelo da revolução de Outubro [...] Para ele, guerra de posição é o cerco do castelo, que é o Estado, por seu exterior que são as estruturas do poder popular. Mas, no fundo, é sempre a mesma história: ou se ataca o castelo de uma só vez - guerra de movimento; ou ele é sitiado - guerra de posição. Não se encontra em Gramsci a concepção de que uma verdadeira ruptura revolucionária pode passar pelo interior do Estado (WEBER; POULANTZAS, 2019, p. 197).

Essa interpretação do intelectual greco-francês está demasiadamente comprometida por não apreender e apresentar com circunspecção a singularidade do imbricamento entre Estado, guerra de posição e guerra de movimento no pensamento revolucionário de Antonio Gramsci. Este, efetivamente, especifica que uma "revolução jacobina" ou uma "revolução de outubro" foram e são correspondentes a uma sociedade civil "primitiva", "gelatinosa ou muito pouco desenvolvida" ("sociedades orientais"), denotando que nesse tipo de sociedade civil a guerra de movimento (de ataque frontal) foi e é a estratégia prevalente na "tomada do poder". Sem embargo, para o autor italiano, em virtude da complexificação e transmutação das "democracias modernas" ("sociedades ocidentais"), a sociedade civil tornou-se robusta por açambarcar um conjunto de associações privadas que se assemelham às trincheiras ou fortificações ${ }^{11}$ que obstaculizam uma "revolução permanente" ou "guerra de manobra". Daí a adequação nesse tipo de sociedade civil hodierna de uma estratégia que combine particularidades da guerra de movimento com especificidades da guerra de posição, que encerra uma "guerra de assédio, tensa, difícil, em que exigem qualidades excepcionais de paciência e espírito inventivo" (GRAMSCI, 2002, p. 256) no processo de luta contra a classe dominantedirigente; concatenando dialeticamente ações político-culturais tanto na sociedade civil quanto na sociedade política por uma nova hegemonia que passa pela superação do bloco histórico capitalista até a construção de um novo bloco histórico comunista ou simplesmente "sociedade regulada12".

Enfim, podemos concluir, contrariando a noção oblíqua de Poulantzas, que Gramsci, inspirado na estirpe marxiana/marxista, bosqueja um processo revolucionário sofisticado que transpassa o Estado Integral, intencionando educar as classes subalternas ${ }^{13}$ para torná-las dirigentes ${ }^{14}$ antes mesmo de serem tãosomente dominantes.

\section{Uma Educação para a Revolução: as contribuições da Pedagogia Histórico-Crítica (PHC)}

De inspiração marxista e gramsciana, a PHC tem em seu bojo o fazer pedagógico como um projeto político de ab-rogação do sistema capitalista. Trata de inserir componentes do campo ético-político 
no desenvolvimento da práxis social a partir da educação, onde o nível de consciência de classe e da realidade é reelaborado e ressignificado pelo senso crítico.

Ao compreendermos que na questão do Estado reside uma das dimensões categoriais chave para ultrapassarmos o senso comum sobre o fazer político e as disputas hegemônicas, é pertinente que nas articulações desse domínio de força elementos de consenso contra-hegemônicos sejam continuamente organizados. Vemos então, na concepção de Estado Ampliado, uma possibilidade de complexificar a relação de forças nos processos decisórios em tensionamento.

Um dos âmbitos de contendas é a educação. No cenário educacional brasileiro essa relação de forças tem ganhado contornos mais díspares à medida da crescente intervenção de aparelhos privados de hegemonia no contexto decisório do fazer escolar, explicitado na área das políticas públicas em educação, tanto na concepção de formação de professores, conteúdos e competências desenvolvidas no chão da escola, como na relação com os fundos públicos destinados ao setor, em variadas categorias de uso, também notadamente instrumentais, como concepção e distribuição de materiais didáticos, modelos didáticos, formação continuada entre tantos componentes com capacidade de inserção de uma ideologia dominante.

Diante do emaranhado jogo de intervenções de entes privados, as concepções de escola e de educação como particularidades civilizatórias e de acesso ao "mundo encantado da meritocracia" apregoados na lógica liberal burguesa, adequam-se para atender aos desígnios do mercado e à ideologia de uma classe dominante atrelada a um projeto de "desenvolvimento do subdesenvolvimento" (OURIQUES, 2013, p. 17), em que a desigualdade socioeconômica ganha enorme importância.

A partir dessa manifesta intenção de retrocesso e antidemocracia no panorama educacional brasileiro, despontam-se alguns teóricos a repensar como explicar e fomentar processos de emancipação e de efetiva capacidade de contestação entre os heterogêneos interesses pedagógicos envolvidos. Assim no esforço de arregimentar uma perspectiva teórica que desse conta da apreensão da questão e do efetivo processo de luta, no intento de ultrapassar o estado de coisas e ir além no processo de disputa das classes subalternas, constrói-se a concepção da Pedagogia Histórico-crítica (PHC ${ }^{15}$ ), que sob a égide do trabalho de Marx, a partir da obra Contribuição à crítica da economia política, iniciou-se em 1984 um novo potencial de análise da educação. A PHC tem como questão central o saber objetivo sobre as políticas educacionais e o papel da escola.

A escola tem uma função política própria e a ela está atrelada a concepção de modo de produção que define o papel da escola e sua utilidade para a lógica burguesa e os interesses das classes dominantes ${ }^{16}$. A escola e a função política dos seus atores podem promover, através da visão crítica não reprodutivista, a consciência dos problemas, das limitações e das expectações do fazer escolar pautado no caráter dialético que explicita o contraditório das articulações históricas e suas condicionantes. 
Assim, no horizonte da PHC há, conforme Saviani (2011), uma forma de via transformadora através da prática dos educadores, no sentido de uma resistência ativa que "não se limita a efetuar a crítica mostrando os limites, insuficiências e equívocos das teorias hoje hegemônicas" (SAVIANI, 2011, p. 26).

Sobre a condição brasileira no processo educacional, Rosar (2018) nos salienta a importância da PHC como movimento de resistência e de organização dos trabalhadores, desde o necessário embate sobre a formação dos professores, majoritariamente de caráter reprodutivista, principalmente com a ampliação da representação dos aparelhos privados neoliberais, e sua reiterada ação de diluição das reivindicações da classe trabalhadora, cooptação e financiamento no âmbito da sociedade civil para a difusão da ideologia hegemônica. E para além, na esfera da prática docente e de suas ações para a educação. A autora apresenta a urgência da tomada de decisões de caráter emancipatório:

Parece inadiável que nesse contexto os educadores militantes compreendam como parte do trabalho docente, efetivar uma disputa teórico-metodológica com as pedagogias oficiais e as pedagogias de resultados, em todos os espaços de educação formal e nãoformal, de modo historicizado e não mecanicista (ROSAR, 2018, p. 92).

A Pedagogia Histórico-Crítica delineia o caminho para o entendimento de que nas práticas escolares há intencionalidades que devem sair do domínio do senso comum à consciência filosófica. Assim, confere importância à apropriação da questão social e do direito a educação como prática pedagógica emancipatória e para além da função técnica, voltada para o sujeito na sua relação com o trabalho e com o mundo em que ele vive e participa.

Elaboração do saber não é sinônimo de produção do saber. A produção do saber é social, ocorre no interior das relações sociais. A elaboração do saber implica expressar de forma elaborada o saber que surge da prática social. Essa expressão elaborada supõe o domínio dos instrumentos de elaboração e sistematização. Daí a importância da escola: se a escola não permite $\mathrm{o}$ acesso a esses instrumentos, os trabalhadores ficam bloqueados $\mathrm{e}$ impedidos de ascender ao nível da elaboração do saber, embora continuem, pela sua atividade prática real, a contribuir para a produção do saber. O saber sistematizado continua a ser propriedade privada a serviço do grupo dominante. Assim, a questão da socialização do saber, nesse contexto, jamais poderia ser assimilada à visão do funcionalismo durkheimiano, porque se inspira toda na concepção dialética, na crítica da sociedade capitalista desenvolvida por Marx (SAVIANI, 2001, p. 67).

A concepção dialética do materialismo histórico inscrita na PHC é da atuação em educação pela mediação no processo social, é, portanto, uma metodologia que usa da prática social existente para construir a sua crítica. Para Saviani, além de Marx, Gramsci é também referência central para a constituição da PHC; e de Gramsci, entre tantas proposições, utiliza-se da categoria de catarse ${ }^{17}$ como elemento que revela a estrutura do processo pedagógico (SAVIANI, 2014).

Duarte (2019) indica que a interpretação da categoria de catarse por Saviani é explorada pela questão didática, no sentido de que:

O processo catártico é um salto qualitativo na ampliação e no enriquecimento das relações entre a subjetividade individual e a objetividade sociocultural. Trata-se de uma transformação, ao mesmo tempo, intelectual, emocional, educacional, política e ética, que modifica a visão de mundo do indivíduo e suas relações com sua própria vida, com a sociedade e com o gênero humano (DUARTE, 2019, p. 3). 
É conveniente nos atentarmos que a educação tem sido uma prática social de dimensões complexas, assim como seus embates e pautas de discussão. As questões objetivas apresentam-se de modo mais óbvio nos confrontos cotidianos, mas as questões de cunho subjetivo, menos aparentes e aquelas que pouco debatemos, são campos que devemos nos debruçar e aprofundar conhecimento, visto que são fulcrais na captação da realidade.

Para Semeraro (2001), a perspectiva de Gramsci da lógica objetiva e subjetiva do conhecimento é elemento ímpar no processo de constituição da progressiva emancipação, a afirmação social e política das classes subalternas. A capacidade de estabelecer uma concepção de mundo e atuação são definidas por um processo de esclarecimento da realidade, constituição da identidade e conhecimento.

(...) 'Toda a realidade objetiva significa exatamente o que é verificado por todos os homens, independentemente de qualquer ponto de vista meramente particular ou de grupo. Mas, no fundo, esta também depende de uma específica concepção de mundo, é uma ideologia' (Q 1456). Por quê? Porque todas as afirmações 'objetivas' de ciência são sempre históricas, construídas, vinculadas aos objetivos predominantes de uma sociedade e, portanto, superáveis (SEMERARO, 2001, p. 99).

De acordo com o autor, em Gramsci, as subjetividades e objetividades na esfera do conhecimento representam uma relação dialética.

No léxico político de Gramsci, o conceito de ideologia não é unívoco, mas complexo, retratado ora como recurso que mascara a realidade ora como força amalgamadora e constitutiva de subjetividades políticas. E, se a ideologia não é um mero 'reflexo' das estruturas materiais, por ter uma autonomia relativa, também não é uma ilusão, uma pura criação da imaginação deformada das pessoas, uma vez que é 'um fato histórico real', operante na conduta dos homens. Na verdade, trata-se sempre de uma popularização de concepções filosóficas, da manifestação concreta de como as pessoas entendem o mundo (SEMERARO, 2001, p. 100).

Quando se compreende as múltiplas determinações da realidade concreta, amplia-se a dimensão crítica de nossa inserção no mundo e descortina-se a possibilidade de encampar um projeto societal de negação da naturalização do mundo burguês e de sua edulcorada ideologia de que todos somos cidadãos e iguais perante a lei.

Para Saviani (2001) a reflexão crítica histórica e historicizadora, proposta no escopo teórico do socialismo, possibilita a consciência e práticas unitárias do proletariado. Ao desnaturalizar as relações sociais, de produção e conhecimento, ou seja, a crítica à cultura, o proletariado com o domínio do saber histórico é capaz de ultrapassar o lugar de sua atuação, assim deve:

\footnotetext{
acumular forças, unificar as lutas, visando a consolidar os avanços e tornar irreversíveis as conquistas feitas, trilhando um caminho sem retorno no processo de reapropriação, por parte das camadas trabalhadoras, do conhecimento elaborado e acumulado historicamente (SAVIANI, 2001, p. 55).
}

No horizonte da revolução socialista, de inspiração leninista, a partir da Revolução de Outubro, Lombardi (2018) indica que a escola era considerada como instituição essencial na formação do novo homem, na produção social de novas relações sociais. Assim a defesa da importância da escola na PHC 
consiste em uma teoria da educação que pensa o lugar social que a escola ocupa, sendo este lugar central e nas determinações objetivas do conhecimento. Desse modo, compreende que os movimentos sociais devem reconhecer essa questão e assim criar condições para que os trabalhadores possam exigir o tipo de escola que querem usufruir no seu direito, e cunhar uma forma organizada para o intento da fase de transição do capitalismo ao socialismo e, assim, para a sociedade comunista.

Considera então que o certame a ser feito no processo de construção de uma sociedade humanizadora está “no campo da difusão de novas concepções de mundo, exige a subversão das práticas pedagógicas dentro e fora da escola" (LOMBARDI, 2018, p. 96).

Desse modo, a PHC contribui para forjar a participação plural e organizada da classe trabalhadora nos processos decisórios no espaço político, visto que oferece contribuição para a concepção dialética do fazer educacional e compreensão histórico-crítica da participação social no processo produtivo e político.

Concluímos que na concepção de Estado erigida por Marx, Poulantzas e Gramsci há a ideia de que, pela contradição e tensão das relações sociais contemporâneas, encontramos subsídios para a elevação da consciência crítico-científica das classes exploradas. As formulações poulantzianas nos remetem à consciência das forças políticas e suas crispações que compõem a condensação do Estado capitalista, que se plasma na complexa relação social motivada pela luta de classes. Marx nos revela que a luta da classe trabalhadora deve ser para além do sistema econômico vigente, no sentido de superar o Estado capitalista e a propriedades privada dos meios de produção. Gramsci, ao indicar a intrínseca relação entre a sociedade política e a sociedade civil, constituintes do Estado Ampliado, nos evidencia a pluralidade de espaços de atuação de grupos sociais hegemônicos e contra-hegemônicos na disputa por suas ideologias e projetos societais.

Neste sentido, a Pedagogia Histórico-Crítica deveras contribui como uma teoria da educação capaz de orientar a prática dos educadores numa perspectiva transformadora "para além do capital". Essa pedagogia pressupõe um labor educativo humanístico-científico que deve ser defendido como um elemento fundamental no embate de classe, na perspectiva de construção de uma interação orgânica com os movimentos sociais e políticos contra-hegemônicos no processo de luta emancipatória do "círculo de ferro" do capital.

\section{Referências:}

BALIBAR, Etienne et al. O Estado em discussão. Porto: Edições 70, 1981.

BIANCHI, Alvaro. O laboratório de Gramsci - Filosofia, História e Política. São Paulo: Alameda, 2008.

BUCI-GLUCKSMANN, Christine. Gramsci e o Estado. Rio de Janeiro: Paz e Terra, 1980.

DUARTE, Newton. A catarse na didática da pedagogia histórico-crítica. Pro-Posições, Campinas, v. 30, 2019. Disponível em <http://www.scielo.br/scielo.php?script=sci_arttext\&pid=S010373072019000100201\&lng=en\&nrm=iso >. Acesso em: 15 abr. 2021. 
ENGELS, Friedrich et al. A questão do Partido. São Paulo: Kairós, 1978.

FONTES, Virgínia. Gramsci, Estado e sociedade civil: anjos, demônios ou lutas de classes? Outubro, n. 31, p. 217-232, 2008.

FOSTER, John Bellamy; HOLLEMAN, Hannah; CLARK, Bert. Imperialismo no Antropoceno. 01. Julho 2019. Montly Review. NY. Disponível em: < https://monthlyreview.org/2019/07/01/imperialismin-the-anthropocene/>. Acesso em: 20 mai. 2021

GRAMSCI, Antonio. Cadernos do cárcere. Rio de Janeiro: Civilização brasileira, v. 3, 2002.

GRAMSCI, Antonio. Cadernos do cárcere. Rio de Janeiro: Civilização brasileira, v. 2, 2001.

JACOMINI, Márcia. O conceito gramsciano de Estado Integral em pesquisas sobre políticas educacionais. Educação e pesquisa, v. 46, p. 01-19, 2020.

LENIN, Vladimir Ilitch. O Estado e a Revolução: o que ensina o marxismo sobre o Estado e o papel do proletariado na revolução. São Paulo: Centauro, 2007.

LOMBARDI, José Claudinei. A revolução soviética e a pedagogia histórico-crítica. In: ORSO, Paulino José; MALANCHEN, Júlia; CASTANHA, André Paulo. (Org.). Pedagogia histórico-crítica, educação e revolução: 100 anos da Revolução Russa. 1 ed. Campinas: Navegando/Armazém do Ipê, 2017.

MARX, Karl. A Guerra Civil na França. São Paulo: Edições Sociais, 1975.

MARX, Karl As lutas de classes na França (1848-1852). Rio de Janeiro: Vitória, 1956.

MARX, Karl. Crítica ao Programa de Gotha. São Paulo: Edições Sociais, 1975.

MARX, Karl. O 18 Brumário de Luis Bonaparte. São Paulo: Abril (Coleção Os Pensadores), 1974.

MARX, Karl. O Manifesto do Partido Comunista. Rio de Janeiro: Vitória, 1960.

MARX, Karl et al. A questão do Partido. São Paulo: Kairós, 1978.

MENDONÇA, Sônia R. O Estado ampliado como ferramenta metodológica. Marx e o marxismo, v. 2, n. 2, p. 27-43, 2014.

OURIQUES, Nildo. Apresentação. In: MARINI, Ruy Mauro. Subdesenvolvimento e revolução. Florianópolis: Insular, 2013.

POULANTZAS, Nicos. O Estado, o poder, o socialismo. São Paulo: Graal, 1985.

POULANTZAS, Nicos. Poder político e classes sociais. Porto: Portucalense, 1971.

ROSAR, Maria de Fátima Felix. Movimentos sociais, educação e revolução. In: ORSO, Paulino José; MALANCHEN, Júlia; CASTANHA, André Paulo. (Org.). Pedagogia histórico-crítica, educação e revolução: 100 anos da Revolução Russa. 1 ed. Campinas: Navegando/Armazém do Ipê, 2017.

SAVIANI, Demerval. Gramsci e a educação no Brasil: para uma teoria gramsciana da educação e da escola. In: Anita Helena Schlesener. (Org.). Filosofia, política e educação: leituras de Antonio Gramsci. 1 ed. Curitiba: UTP, 2014, v. 1. 
SAVIANI, Demerval. Pedagogia histórico crítica, educação e revolução. In: ORSO, Paulino José; MALANCHEN, Júlia; CASTANHA, André Paulo. (Org.). Pedagogia histórico-crítica, educação e revolução: 100 anos da Revolução Russa. 1 ed. Campinas: Navegando/Armazém do Ipê, 2017.

SAVIANI, Demerval. Pedagogia Histórico-Crítica. 11 ed. Campinas: Autores Associados, 2011.

SEMERARO, Giovanni. Anotações para uma teoria do conhecimento em Gramsci. Rev. Bras. Educ. 2001, n. 16, p. 95-104. Disponível em: < http://www.scielo.br/scielo.php?script=sci arttext\&pid=S141324782001000100010\&lng=en\&nrm=iso >. Acesso em: 15 abr. 2021.

SOARES, Rosemary D. A concepção gramsciana do estado e o debate sobre a escola. Ijuí: UNIJUÍ, 2000.

WEBER, Henri.; POULANTZAS, Nicos. Entrevista com Nicos Poulantzas: o Estado e a transição ao socialismo. Cadernos Cemarx, Campinas, SP, n. 12, p. 189-216, 2019. Disponível em: $<$ https://econtents.bc.unicamp.br/inpec/index.php/cemarx/article/view/11322>. Acesso em: 16 mar. 2021.

\footnotetext{
Notas

${ }^{1}$ Mestre em História Econômica pela FFLCH/Universidade de São Paulo. Doutoranda em Educação pela Unifesp. Possui Licenciatura Plena em História e Pedagogia. Pesquisadora do Grupo de Estudo e Pesquisa em Política Educacional e Gestão Escolar (GEPPEGE/Unifesp):dgp.cnpq.br/dgp/espelhogrupo/8103743066066390.Lattes; http://lattes.cnpq.br/1155653092420308. Orcid: http://orcid.org/0000-0002-1811-8387.E-mail: daniellerezera@yahoo.com.br

${ }^{2}$ Mestre em Ciências Sociais. Doutorando em Educação pela Universidade Federal de São Paulo (Unifesp). Pesquisador do Grupo de Estudo e Pesquisa em Política Educacional e Gestão Escolar (GEPPEGE/Unifesp): dgp.cnpq.br/dgp/espelhogrupo/8103743066066390.Lattes: http://lattes.cnpq.br/2364672180861116.Orcid: http://orcid.org/00 00-0001-7468-0473. E-mail: walson.lopes@yahoo.com

${ }^{3}$ No livro Estado e Revolução, Lenin chega a afirmar que “[...] Quem só reconhece a luta de classes não é ainda marxista e pode muito bem não sair dos quadros do pensamento burguês e da política burguesa. Limitar o marxismo à luta de classes é truncá-lo, reduzi-lo ao que é aceitável para a burguesia. Só é marxista aquele que estende o reconhecimento da luta de classes ao reconhecimento da ditadura do proletariado" (LENIN, 2007, p. 59, grifos originais]. Para um profícuo debate sobre essa problemática, consultar O Estado em discussão, livro organizado e publicado pela Edições 70, contendo argumentações de Balibar, Poulantzas, Gruppi, Buci-Glucksmann e outros.

${ }^{4}$ WEBER, H.; POULANTZAS, N. Entrevista com Nicos Poulantzas: o Estado e a transição ao socialismo. Cadernos Cemarx, Campinas, SP, n. 12, p. 189-216, 2019. Disponível em:

<https://econtents.bc.unicamp.br/inpec/index.php/cemarx/article/view/11322>. Acesso em: 16 mar. 2021

5 "O conceito de hegemonia reveste igualmente uma outra acepção, a qual não é de facto indicada por Gramsci. Veremos, com efeito, que o Estado capitalista e as características específicas da luta de classes numa formação capitalista tornam possivel o funcionamento de um "bloco no poder", composto de várias classes ou fracções politicamente dominantes. Entre essas classes ou fracções dominantes, uma delas detém um papel dominante particular, o qual pode ser caracterizado como papel hegemônico". (POULANTZAS, 1971, p. 166-167, grifos originais)

${ }^{6}$ Mesmo reconhecendo a relevância do debate sobre a sociedade civil em Hegel, Marx e Gramsci, instado por Bobbio, não abordaremos essa questão neste artigo. Remetemos às pesquisas de Bianchi (2008) e Jacomini (2020).

7 "Diversas são as interpretações do conceito de Estado Integral de Gramsci, temos inclusive alguns casos de interpretações reformistas ou mesmo liberais. Entretanto, encontramos em seus escritos um conjunto significativo de elementos que nos leva a compreender sua elaboração em uma perspectiva que, ao voltar a atenção à superestrutura, não desconsidera a relação dialética desta com a estrutura, ou seja, não desdenha das relações de produção e de seu estado de desenvolvimento" (JACOMINI, 2020, p. 07, grifos nossos).

8 “[...] Os aparelhos privados de hegemonia ligam-se direta ou indiretamente ao solo da produção, permitindo compreender como diferentes tendências e contradições são traduzidas em formas mais ou menos organizadas de cultura e de consciência e chegam a condensar-se como projetos políticos" (FONTES, 2018, p. 221).

9 “[...] Os aparelhos privados de hegemonia ligam-se direta ou indiretamente ao solo da produção, permitindo compreender como diferentes tendências e contradições são traduzidas em formas mais ou menos organizadas de cultura e de consciência e chegam a condensar-se como projetos políticos" (FONTES, 2018, p. 221).

10 "Rompendo resolutamente com uma concepção da ideologia como ideologia-ilusão ou como simples sistema de ideias, Gramsci estende a análise dos aspectos mais conscientes das ideologias a seus aspectos inconscientes, implícitos, materializados nas práticas, 
às normas culturais aceitas ou impostas. As ideologias funcionam como agentes de unificação social, como cimento de uma base de classe" (BUCI-GLUCKSMANN, 1980, p. 83).

11 Ocidente e Oriente não são meramente localizações geográficas nos estudos gramscianos: “[...] No Oriente, o Estado era tudo, a sociedade civil era primitiva e gelatinosa; no Ocidente, havia entre o Estado e a sociedade civil uma justa relação e, ao oscilar o Estado, podia-se imediatamente reconhecer uma robusta estrutura da sociedade civil. O Estado era apenas uma trincheira avançada, por trás da qual se situava uma robusta cadeia de fortalezas e casamatas; em medida diversa de Estado para Estado, é claro, mas exatamente isto exigia um acurado reconhecimento de caráter nacional”' (GRAMSCI, 2002, p. 262).

${ }^{12}$ Segundo ponderação de Bianchi, "Guerra de movimento e guerra de posição encontrar-se-iam assim em um nexo indissociável e diriam respeito a diferentes momentos da luta pela afirmação de uma nova ordem política e social. O desenvolvimento dado por Gramsci à questão indica que esse nexo é análogo àquele que se estabelece no interior de seu conceito de Estado integral. Os dois planos conceituais encontram-se, desse modo, sobrepostos, e é possível afirmar que a guerra de movimento predomina na luta contra a sociedade política e a guerra de posição afirma sua supremacia na luta na sociedade civil” (BIANCHI, 2008, p. 209, grifos originais). ${ }^{13}$ É preciso considerar que “[...] as ideias e as opiniões não 'nascem' espontaneamente no cérebro de cada indivíduo: tiveram um centro de formação, de irradiação, de difusão, de persuasão, houve um grupo de homens ou até mesmo uma individualidade que as elaborou e apresentou na forma política de atualidade" (GRAMSCI, 2002, p. 82).

14 “[...] No 'Estado ampliado', a fórmula revolucionária para a luta política é conceituada por Gramsci como a da 'hegemonia civil’: implica o envolvimento de grandes massas na resolução dos seus problemas, através da participação no complexo de associações da vida civil que se expandem na estrutura de massas das democracias modernas. Essas associações, os 'aparelhos privados de hegemonia', passam a constituir verdadeiras 'trincheiras' de combate pela obtenção de posições de direção e governo da sociedade" (SOARES, 2000, p. 43, grifos nossos).

${ }_{15} \mathrm{O}$ autor indica que na concepção da PHC toma o conceito do Estado ampliado e o conceito de hegemonia atrelado a ele. Entende que a figura do intelectual está no campo do organizador da classe, naquele que implica ser o partido que de modo ampliado é político e ideológico. "E aqui nós encontramos a escola que se configura como um partido ideológico, cuja função precípua é elaborar intelectuais de diversos níveis, tarefa que se cumpre pela disciplina coroada pela catarse." (Saviani, 2011, p. 9).

${ }^{16}$ Saviani (2001) organiza a questão tomando como elemento central o conceito de reificação de Marx (Verdinglichung) expressa na ideia de um tipo de alienação das relações sociais, que naturaliza a sua coisificação. No livro o Capital, tomos I ao III, a questão é discutida como expressão do processo de mercantilização das relações sociais, em que elementos mistificadores se apresentam no processo de valorização da mercadoria, ocultando a origem das condições do processo produtivo que levam a constituição real do valor e apropriação de trabalho não pago (MARX, 1983).

17 "Pela catarse o processo educativo atinge seu ápice propiciando aos educandos atingir uma concepção superior, liberta de toda magia e bruxaria. Pela catarse dá-se a passagem do nível puramente econômico ao momento ético-político. Igualmente, pela catarse dá-se a elaboração superior da estrutura em superestrutura na consciência dos homens. Ou seja, ocorre a assimilação subjetiva das condições objetivas permitindo a passagem da condição de classe-em-si para a condição de classe-para-si. É, enfim, pela catarse que tudo aquilo que era objeto de aprendizagem se incorpora no próprio modo de ser dos homens operando uma espécie de segunda natureza que transforma qualitativamente sua vida integralmente, isto é, no plano das concepções e no plano da ação" (SAVIANI, 2001, p. 22). 